\title{
Brain Organoids and Consciousness: Late Night Musings Inspired by Lewis Thomas
}

\author{
Joseph J. Fins
}

Division of Medical Ethics, Weill Cornell Medical College, New York, NY, USA; Visiting Professor of Law, Yale Law School, New Haven, CT, USA

Corresponding author: Email. jjfins@med.cornell.edu

When I was a kid, the late Lewis Thomas was my hero. A gifted writer and physician scientist, truth be told, he still is. Thomas brought his poetic prose to science and illuminated the excitement of mid-century medicine informed by his work as an immunologist and concern for our ecosystem, both natural and manmade. In his most famous work, The Lives of a Cell, ${ }^{1}$ Thomas likened the earth to a single cell. His essays are a perfect blend of Watson and Crick, Rachel Carson, and Montaigne, one of his favorite writers. ${ }^{2}$

One characteristic of Thomas' prose was the ability to make large points starting with careful depictions of intricate biological processes. ${ }^{3}$ Nothing was beyond his reach or escaped his scrutiny. His eclectic career included stints as a pathologist, and it is there that he gained his powers of observation. Or perhaps his power of observation led to his work as a pathologist. Either way, the question illustrates the nature-nurture, push and pull in his writing as he contemplated our place in nature and the interplay of high-end clinical investigation with exemplary prose. His talents were justly recognized with both the Lasker Prize and the National Book Award. ${ }^{4}$

With this provenance, I began to wonder what Thomas might have thought about brain organoids, three-dimensional clusters of brain tissue derived from stem cells. ${ }^{5,6}$ Sometimes referred to as minibrains, their origins and organization prompt questions about their capacity for sentience and consciousness. Prominent neuroethicists have already engaged in a lot of handwringing over these developments, calling as is usually done, for caution and a prudential ethic. ${ }^{7,8,9}$ This is generally a good response to novel scientific developments, but are these concerns justified by the science and our current understanding of consciousness?

When we encounter brain organoids in a petri dish, they are often beautifully projected with colorful fluorescent stains. If you were to squint and let your imagination wander, you could envision the outlines of a cerebral cortex. You have to fight off the anthropocentric urge and remember that they are but little globs of cells, each a few millimeters across, and off the grid. They have neither their own blood supply nor are they connected to brain networks. Yet, given their origins, you still ask: do they think, feel, or have ideas of their own? And if they do, are they bothered, or amused, by our thinking about them?

Despite their fine pedigree, I doubt these cells are conscious. Consciousness requires a web of distributed neural networks, or neural correlates of consciousness, ${ }^{10}$ a degree of complexity that these organoids, or even clusters of organoids called assembeloids, could ever possibly have. While they may have some degree of responsiveness to their environment, these displays are more trophic than sentient. While they will prove useful to the study of neural processes, their isolation likely precludes the higherorder functions which consciousness necessitates.

But frankly, I do not know. The only consciousness I can know is my own. Even as I write these words I do so with no assurance that a sentient audience will understand what I have written. The consciousness of a brain organoid is as imponderable to me as the inner life of you, the reader. I can speculate all I want, but ultimately, each is shrouded in both mysteries, if not dura mater.

In Late Night Thoughts on Listening to Mahler's Ninth Symphony, Lewis Thomas urged humility when speculating about consciousness. With a cautionary note against grand pronouncements, he wrote: 
I am entitled to say, if I like, that awareness exits in all the individual creatures on the planet worms, sea urchins, gnats, whales, subhuman primates, the lot. I can say this because we do not know what we are talking about; consciousness is so much a total mystery for our own species that we can not fathom its existence in others. ${ }^{11}$

By analogy, what applies to the animal kingdom applies to organoids from our own species. But all is not lost. Thomas' writings about the natural world might yet be revelatory.

Thomas had a fascination with social insects, ants and termites that work together to achieve what no single insect could do alone. His descriptions of their creations are elegiac writing of termites who “... organize in platoons and begin stacking up pellets to precisely the right height, then turning the arches to connect the columns, constructing the cathedral and its chambers in which the colony will live out its life for the decades ahead..."12 The image conjures up the modernist spires of Gaudi's still unfinished cathedral, La Sagrada Familia in Barcelona.

And yet, the termite does not possess an aesthetic sense, much less consciousness of his artistry. There is, according to Thomas, "...nothing at all wonderful about a single termite..." 13 The majesty of their sand castles comes from their collective work. Driven by chemical signals coded into their genome, a termite colony is capable of what no single termite could achieve alone. Thomas likens the collective efforts of social insects to "...the working parts of an immense central nervous system: the termite colony is an enormous brain on millions of legs; the individual termite is a mobile neurone." ${ }^{\text {" }}$

Thomas sums up the termite colony as a "mediative brain on a million legs." 15 Beyond the beauty of the metaphor, the image is scientifically useful. It helps to illustrate an emergent phenomenon in which the parts come together to create something greater than its elements. ${ }^{16}$ The emergence of early life ${ }^{17}$ or mind from matter has been held up as an example of an emergent phenomenon, the latter proposed by C.D. Broad in 1925. ${ }^{18}$ To this, we might add the work of termites in a huddle whose game plan, not surprisingly, resides in their species' own DNA, itself a product or emergent phenomenon.

What is true of a single nucleotide of DNA-or the hard working termite in a colony-is also true of brain organoids, which have shown the ability to self-organize developmentally assisted by the provision of cell culture scaffolding. ${ }^{19}$ Each becomes an element of something far greater than itself. Their individual contributions are essential in allowing the physical realm to transcend itself and become something majestic.

While this would suggest some sort of dualism, the preservation of emergent phenomena from DNA to termites to organoids onto human consciousness is a nod toward evolutionary biology. In this way, the example of the termite colony bridges two competing theories of consciousness. On the one hand is the centrality of emergence advanced by David Chalmers. ${ }^{20}$ On the other are Darwinian perspectives espoused by Gerald Edelman and Guilio Tononi ${ }^{21}$ and John Searle. ${ }^{22}$ The conservation of emergent processes across an evolutionary continuum suggests the possibility of a theoretical convergence. More recently, this has been described as swarm intelligence and applied to artificial intelligence. ${ }^{23}$ Yes, there is much to be learned from the termite colony and the prescience of a Lewis Thomas essay.

But we are still left with the unanswered question about consciousness and the single organoid. Yet despite this uncertainty, bioethicists voice concerns about their sentience. Though of academic import, the moral status of the brain organoid pales in comparison with the more pressing question of respect for persons diagnosed with disorders of consciousness. ${ }^{24,25}$ Although their consciousness can never fully be known, volitional functional neuroimaging studies in many patients are highly suggestive of the presence of consciousness. ${ }^{26,27}$ Given this, it strikes me as beyond ironic that there is ethical concern about brain organoids and so little worry about individuals with severe brain injury who continue to suffer from pervasive neglect. ${ }^{28}$ Such a preoccupation with scientific novelty discounts both richer notions of consciousness and regard for a marginalized community.

While this would seem a criticism of those whose focus is on the organoid and not on the bigger picture, it is meant as a constructive call for a more capacious view of our responsibilities. If we have compassion for the organoid, we certainly should embrace our obligations to those in liminal states of consciousness who have the capacity for suffering. ${ }^{29}$ It is the least we can do. 
We affirm our humanity by recognizing our debt to biology. At our core, our organoids and ourselves are not so far apart. Nearly 50 years ago, Lewis Thomas made this connection when writing about the bacterial origins of mitochondria, organelles which inhabit all our cells:

...This is a new kind of information, for me, and I regret somewhat that I cannot be in closer touch with my mitochondria. If I concentrate, I can imagine that I feel them; they do not quite squirm, but there is, from time to time, a kind of tingle. I cannot help thinking that if only I knew more about them, and how they maintain our synchrony, I would have a new way to explain music to myself. ${ }^{30}$

As I read these reflections from The Lives of the Cell, I thought of our contemporary relationship with brain organoids. Over the coming decades, we will come in closer touch with them, and, through this convergence, become more conscious of our shared biology.

\section{Notes}

1. Thomas L. The Lives of a Cell. New York: The Viking Press; 1974.

2. Heitman D. Our contemporary Montaigne: He made candor literary. Humanities: The Magazine of the National Endowment for the Humanities; 2015 March/April; available at https://www.neh.gov/ humanities/2015/marchapril/feature/our-contemporary-montaigne-he-pioneered-the-personalessay-and-ma (last accessed 7 Mar 2021).

3. Rosenblatt R. Lewis Thomas. The New York Times 1993 November 21: 50 (sect. 6); available at https://www.nytimes.com/1993/11/21/magazine/lewis-thomas.html?searchResultPosition=1 (last accessed 3 Mar 2021).

4. Weissmann G. Lewis Thomas. Biographical Memoirs. Vol. 85. Washington, DC: The National Academies Press; 2004:315-35.

5. Lancaster MA, Renner M, Martin C-A, Wenzel D, Bicknell LS, Hurles ME, et al. Cerebral organoids model human brain development and microcephaly. Nature 2013;501:373-9.

6. Lancaster MA, Knoblich JA. Generation of cerebral organoids from human pluripotent stem cells. Nature Protocols 2014;9:2329-40.

7. Lavazza A, Massimini M. Cerebral organoids: Ethical issues and consciousness assessment. Journal of Medical Ethics 2018; 44(9):606-10.

8. Farahany NA, Greely HT. The ethics of experimenting with human brain tissue. Nature 2018;556 (7702):429-32.

9. Koplin JJ, Savulescu J. Moral limits of brain organoids research. Journal of Law, Medicine \& Ethics 2019;47:760-7.

10. Boly M, Massimini M, Tsuchiya N, Postle BR, Koch C, Tononi G. Are the neural correlates of consciousness in the front or in the back of the cerebral cortex? Clinical and neuroimaging evidence. Journal of Neuroscience 2017;37(40):9603-13.

11. Thomas L. Late Night Thoughts on Listening to Mahler's Ninth Symphony. New York: The Viking Press; 1983:159-60.

12. See note 11, Thomas 1983, at 60 .

13. See note 11, Thomas 1983, at 60 .

14. See note 11, Thomas 1983, at 160 .

15. See note 11, Thomas 1983, at 60.

16. Martin A, Helmerson K. Emergence: The remarkable simplicity of complexity. The Conversation; 2014 Sept 30; available at https://theconversation.com/emergence-the-remarkable-simplicity-ofcomplexity-30973 (last accessed 7 Mar 2021).

17. Balazs AC, Epstein IR. Emergent or just complex? Science 2009;325(5948):1632-4.

18. Broad CD. The Mind and Its Place in Nature. London: Routledge; 2008 (Reprint of 1925, 1st ed.).

19. Lancaster MA. Guided self-organization and cortical plate formation in human brain organoids. Nature Biotechnology 2018;35:659-66. 
20. Chalmers DJ. Consciousness and its place in nature. In: Stitch SP, Warfield TA, eds. The Blackwell Guide to Philosophy of Mind. Oxford: Blackwell Publishing Ltd.; 2003:102-42.

21. Edelman GM, Tononi G. A Universe of Consciousness: How Matter Becomes Imagination. New York: Basic Books; 2000.

22. Searle J. Theory of mind and Darwin's legacy. Proceedings of the National Academy of Sciences of the United States of America 2013;110(2 Suppl):10343-8.

23. Beni G, Wang J. Swarm intelligence in cellular robotic systems. In: Dario P, Sandini G, Aebischer P, eds. Robotics and Biological Systems: Towards a New Bionics? Berlin and Heidelberg: SpringerVerlag; 1993:703-12.

24. Fins JJ. Rights Come to Mind: Brain Injury, Ethics and the Struggle for Consciousness. New York: Cambridge University Press; 2015.

25. Edlow BL, Claassen J, Schiff ND, Greer DM. Recovery from disorders of consciousness: Mechanisms, prognosis and emerging therapies. Nature Reviews Neurology 2021;17(3);135-6.

26. Monti MM, Vanhaudenhuyse A, Coleman MR, Boly M, Pickard JD, Tshibanda L, et al. Willful modulation of brain activity in disorders of consciousness. New England Journal of Medicine 2010;362(7):579-89.

27. Bardin JC, Fins JJ, Katz DI, Hersh J, Heier LA, Tabelow K, et al. Dissociations between behavioural and functional magnetic resonance imaging-based evaluations of cognitive function. Brain 2011;134(3):769-82.

28. Fins JJ. When no one notices: Disorders of consciousness and the chronic vegetative state. The Hastings Center Report 2019;49(4):14-7.

29. Fins JJ, Bernat JL. Ethical, palliative, and policy considerations in disorders of consciousness. Neurology 2018;91(10):471-5.

30. See note 1, Thomas 1974, at 73 (Organelles as organisms).

Cite this article: Fins, J. J. 2021. Brain Organoids and Consciousness: Late Night Musings Inspired by Lewis Thomas. Cambridge Quarterly of Healthcare Ethics 30: 557-560, doi:10.1017/S0963180121000037 


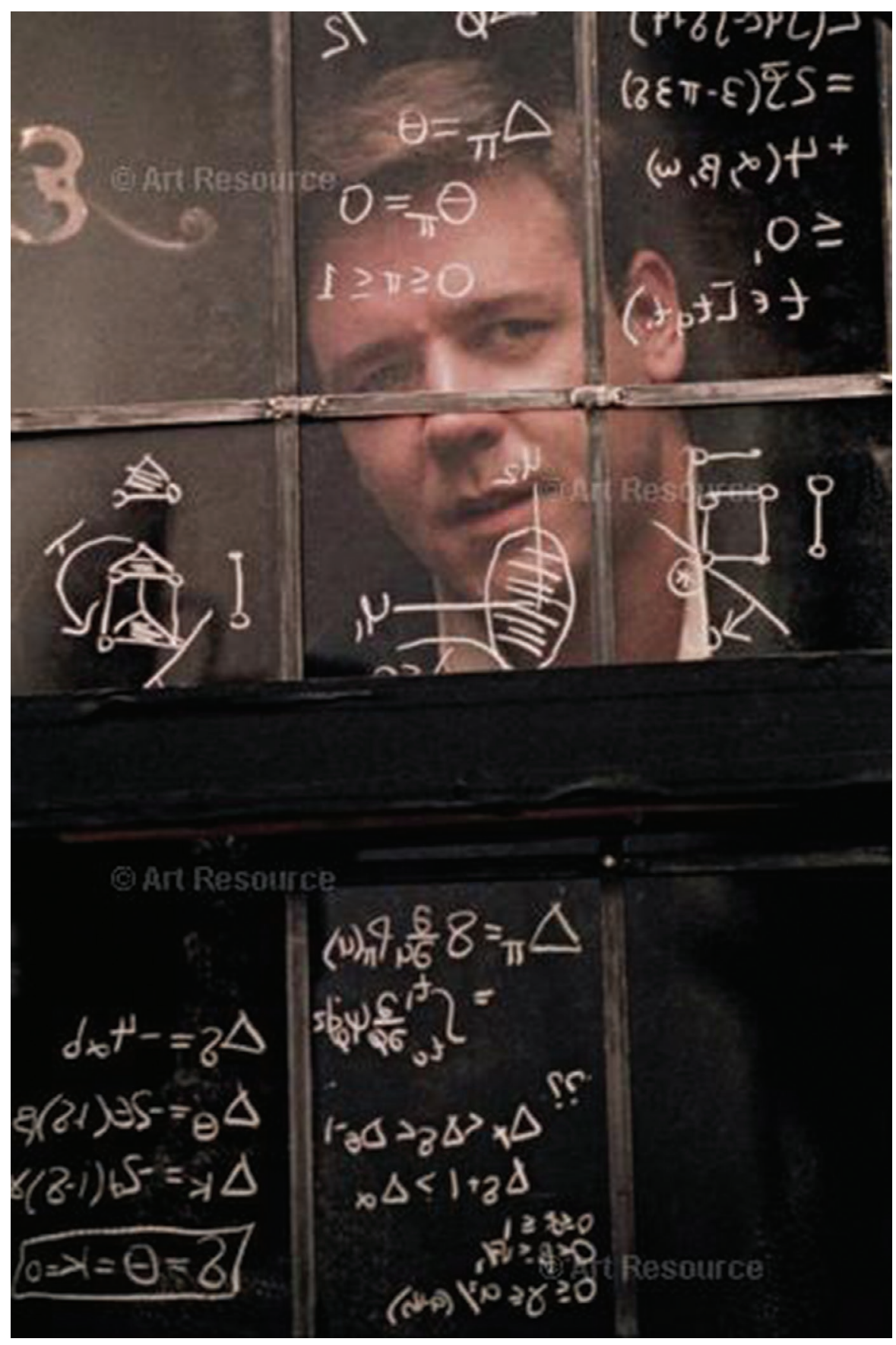

A Beautiful Mind, 2001. Directed by Ron Howard. Russell Crowe. Photo Credit: Universal Studios/Dreamworks/Eli Reed/Album/Art Resource, NY.

Photo Credit: Album / Art Resource, NY. Reproduced by permission. 